Eastern Illinois University

The Keep

Faculty Research and Creative Activity

Sociology/Anthropology

January 2013

\title{
The Economic Deterioration of the Family: Historical Contingencies Preceding the Great Recession
}

Michael D. Gillespie Ph.D.

Eastern Illinois University, mgillespie@eiu.edu

Follow this and additional works at: http://thekeep.eiu.edu/sociology_fac

Part of the Sociology Commons

\section{Recommended Citation}

Gillespie, Michael D. Ph.D., "The Economic Deterioration of the Family: Historical Contingencies Preceding the Great Recession" (2013). Faculty Research and Creative Activity. 4.

http://thekeep.eiu.edu/sociology_fac/4

This Article is brought to you for free and open access by the Sociology/Anthropology at The Keep. It has been accepted for inclusion in Faculty Research and Creative Activity by an authorized administrator of The Keep. For more information, please contact tabruns@eiu.edu. 
The Economic Deterioration of the Family:

Historical Contingencies Preceding the Great Recession

\author{
Michael D. Gillespie, Ph.D. ${ }^{\dagger}$ \\ Eastern Illinois University
}

The "Great Recession" in the United States exposed contradictions between the economic wellbeing of families and capital that developed in the decades prior to this latest downturn. Using social structure of accumulation theory, a qualitative institutional analysis, and quantitative time-series models, this article investigates historicallycontingent relations between the nature of public assistance, family economic deterioration, and capital accumulation. To sustain the circuit of capital, I argue that the family propped up economic growth first through public cash assistance and then through private expenditures, the latter of which lead to the economic deterioration of families dependent on unprecedented levels of debt.

$$
\text { mgillespie@eiu.edu }
$$

Keywords: family debt; poverty; economic deterioration; capital accumulation; welfare

JEL Codes: I38 Government Policy; Provision and Effects of Welfare Programs

D1 Household Behavior and Family Economics

P46 Consumer Economics; Health; Education and Training; Welfare, Income, Wealth, and Poverty

Sociology $\quad 0749$ Market structures \& consumer behavior

Codes: $\quad 1941$ Sociology of the family

0925 Sociology of political systems, politics, \& power

${ }^{\dagger}$ I extend my gratitude to Susan M. Carlson for her on-going support, feedback, comments, and camaraderie. I would also like to thank Steve Pressman and Robert Scott for their comments, Terrence McDonough for his encouragement, and the important and critical comments received from the peer reviewers. 
Running Head: The Economic Deterioration of the Family

\section{Introduction}

The "Great Recession” of the United States that began in December 2007 was preceded by mounting social and economic problems of middle- and working-class families. While those who perpetually live in or near poverty are further marginalized during deep recessions, the most recent economic downturn swelled these ranks with middle-income households. These "typical” American families who contributed to the resurging U.S. economy following the Great Depression and World War II, now exemplify the economic deterioration leading to the most recent recession.

When compared historically, contradictions emerge between the economic conditions for the reproduction of families and for the reproduction of profitability within an expanding capitalist society. Family income from employment has experienced a decade-long decline as both capital accumulation and consumer debt have dramatically increased. For example, between 1948 and 2007, the proportional share of total income held by poor and working class families, the lowest 40 percent, decreased by 18.8 percent as the top 5 percent, the economic elite, experienced a 17.5 percent increase (U.S. Census Bureau 2009). Moreover, the ratio of total household debt to asset values increased from 18 cents to 55 cents per dollar as after-tax corporate profits rose over 600 percent (Bureau of Economic Analysis 2009; Federal Reserve Board of Governors 2010a). As the latest validation of these trends, the "Great Recession" exposed the ongoing deteriorating conditions of existence for low-, working-, and middle-income families as a social class.

Therefore, this research investigates these contradictions and their historical conditions by asking: Why has the economic condition of the family in the United States deteriorated after World War II? 
Running Head: The Economic Deterioration of the Family

A growing body of work on the political and economic shifts prior to the "Great Recession” concentrates on financial programs devised by investors, often in relation with governmental bureaucrats or elected officials (McLean and Nocera 2010; Sorkin 2009). Inclusive of historical and comparative accounts of economic crises (Reinhart and Rogoff 2009) and the on-going housing crisis (Kotz 2009), a broad, historical concept of the family is missing from most of this work. Some social-economic research reflects the importance of banking and credit for low-wage households (Blank and Barr 2009), and the associated growth of debt poverty (Goodman 2009; Pressman and Scott 2009b), yet literature on the macro-economic links between financial institutions and the family institutions within the circuit of capital is inadequate (Barba and Pivetti 2009).

To address this gap and the research question, I first present an historicalinstitutional conception of the family and, using social structure of accumulation theory, conduct a qualitative institutional analysis of the political economy of the family in the United States after World War II. Next, four quantitative time-series models investigate historically-contingent relations between family economic deterioration, shifts in income assistance, and financial deregulation. I argue that the family, when needed, was once able to access public support and cash assistance to reproduce labor in the circuit of capital. However, conditioned by financial deregulations, waning public welfare, and stagnating wages from employment in the late 1970’s to the "Great Recession” institutionalized consumer lending practices maintained the family as a durable market, even as their economic wellbeing was mired under unprecedented levels of debt. 
Running Head: The Economic Deterioration of the Family

\section{Theoretical Frame: The Historical-Institutional Family and SSA Theory}

Typical attention by the social sciences on the economic conditions of families is on the lived experiences of poor, near poor or low-income families (Collins and Mayer 2010; Wilson 1996), especially single-mother families in the welfare system (Hays 2003; Sidel 2006; Turner, Danziger, and Seefeldt 2006) and the downward mobility of middleclass families within changing labor markets (Newman 2006; Pattillo-McCoy 1999; Warren and Tyagi 2003). Where the literature includes certain family groups within specific social institutions, minimal attention has been given to the economic conditions of the family combining the poor, near-poor, and working- and middle-classes.

These limitations could stem from traditional family research that concentrates on individuals within families, broader kinship groups, and their immediate social milieu (White and Klein 2008). Other social-institutional analyses range from rational choice and econometric models of probable individual behavior (Almond 2006; Becker 1991) to grand, functionalist conceptions within an interdependent cohesive system (Parsons and Bales 1955; Swenson 2004). When applied, these approaches often link the economic deterioration of families to inferior investments in human capital or the requirements of social differentiation (Collins 1975).

The family as a political and economic social institution is more complex, and to analyze the contradictions between capital accumulation and family economic deterioration, an historical-institutionalist approach is preferred. This approach links qualitative circumstances with quantitative associations to analyze the structural, historical, and material conditions of existence for families (Marx 1998; Mills 1959). 
Running Head: The Economic Deterioration of the Family

As U.S. capitalist society develops over time, the economy became its major organizing factor and extended periods of prosperity and growth link the needs of capitalist profit and accumulation to the supportive contributions of families. The political economy impacts the nature of institutions as the capitalist mode of production shapes the development of the family as a social institution within the circuit of capital (Creed 2000). Foremost, no other enterprise or industry exists within capitalist society specializing in the production and reproduction of human labor as an input to the production of commodities and services or for their subsequent consumption. The political and economic realities of the U.S. capitalist system following WWII promoted a middle-class family as an ideal through marriage and childbearing norms, patterns of socialization, and expanding consumer credit to foster consumption. Backed by educational, housing, financial, and other social programs, the family was re-established in somewhat changed form as the primary institution for social reproduction (Coontz 1992).

At historical moments, the competitive and innovative nature of capitalist development promoted, supported, and benefitted unevenly from these essential reproduction, socialization, or consumption roles of the family institution (Dickinson and Russell 1986; Engels [1884] 2001; Zaretsky 1976). Therefore, this framework analyzes such historically-contingent political and economic shifts in the family-capital relationship, and the dialectical character of circumstances that both shape and are shaped by families attempting to fulfill their institutional roles while within their conditions of existence. 
Running Head: The Economic Deterioration of the Family

Social structure of accumulation theory posits that at particular historical moments a distinctive set of economic, social, and political institutions, a social structure of accumulation (SSA), come together in a phase of consolidation providing conditions necessary for strong and persistent capital accumulation by regulating class conflict and competition. Over time, SSAs become ever more complex due to inherent contradictions and labor/citizen unrest, and ultimately breakdown leading to economic decline during the decay phase, which overlaps with a following lengthy period of institutional restructuring during the exploration phase. Eventually a new SSA consolidates fostering renewed economic growth (Gordon, Edwards, and Reich 1982). SSA theory, anchored in Marxist economics, combined capital-labor relations within the mode of production with historically-contingent social institutions that mitigate contradictory social conditions.

SSA theorists (Bowles, Gordon, and Weisskopf 1990) have provided a detailed analysis of the period of sustained economic growth immediately after World War IIthe post-WWII SSA in the United States. ${ }^{1}$ This SSA has four institutional pillars-a limited capital-labor accord, the capitalist-citizen accord, Pax Americana, and muted inter-capitalist rivalry. Supported by a financial regulatory structure, these core institutions impinge most directly on capital accumulation (Gordon, Edwards, and Reich 1982; Wolfson 1994). The critical position of the state to support accumulation has been discussed within core SSA institutions, but has been undertheorized. O’Connor’s (1973) theory of the capitalist state is argued here to be consistent with the SSA approach, where stable conditions amenable for accumulation are a product of the state's contradictory fiscal legitimization and accumulation roles (Carlson, Gillespie, and Michalowski 2010). However, these roles are not solely fiscal, but part of broader strategic policy 
Running Head: The Economic Deterioration of the Family

interventions attempting to balance relations between class factions (Gough 1979; Jessop 2007). The capitalist state is therefore a welfare state within a modified capitalist-statecitizen accord to balance the wellbeing of capital and citizens and generate conditions necessary for a vigorous circuit of capital.

Theoretically, the family intersects the capital-labor and capitalist-citizen accords, and the financial regulatory structure. However, SSA theory, rooted in Marxist economics, has focused on class conflicts between labor and capital, with minimal consideration of household labor and internal family dynamics below an institutional level (Kotz 1994; O'Hara 1995). To supplement SSA theory, the historical-institutional family reproduced current and future labor power for the capital-labor accord, socialized members within the capitalist system, and provided a durable market for consumption. Bolstered by access to credit and banking, middle-class families supported system stability and legitimacy within their conditions of existence.

\section{Institutional Analysis: Family Economic Deterioration over the Post-WWII SSA}

Preceding Exploration: 1933-1948

A consolidated SSA is the product of its preceding exploration phase. For the post-WWII SSA, the 1933-1948 period of exploration, including core years of the Great Depression and World War II, generated high levels of structural unemployment and labor unrest, conditions addressed by the National Labor Relations Act, Fair Labor Standards Act, and Taft-Hartley Act. This capital-labor accord targeted enterprises most fundamental to economic growth, allowed labor to organize and bargain collectively, provided job safety and security, and, for families, real wages and cost of living increases were indexed to productivity, balancing production with new norms of consumption. The 
Running Head: The Economic Deterioration of the Family

capitalist-state-citizen accord, through the Social Security Act, mediated labor-market risks for families with social insurance for the unemployed and in old age and meanstested public assistance through Aid to Dependent Children (ADC) and General Assistance when breadwinners were displaced from the labor force. To generate confidence and stabilize demand the Glass-Steagall Banking Act compartmentalized the banking industry and restrained interest rates, the Securities and Exchange Act established federal oversight of banks and markets, and the Federal Deposit Insurance Corporation promoted thrift. Finally, the National Housing Acts of 1934 and 1938 institutionalized the Federal Housing Administration (FHA) and Federal National Mortgage Association (FNMA) to promote the home-ownership.

In sum, the New Deal created a capitalist welfare state and the means for laboring and middle class families to support the reproduction of labor power with the consumption of capitalist goods, simultaneously fortifying the circuit of capital and aggregate demand. However, the post-WWII SSA only included those families covered by the capital-labor and capitalist-state-citizen accords. Access to real living wages, job security, health, education, and a family home left agricultural workers, domestic servants, the self-employed, small business owners, and their employees at the margins. For the latter, work was reinforced by restricting aid and relief necessitating their labor power in low-wage sectors. Through both sets of relations, capital was provided an adequate supply of labor for stratified positions, and durable, but unequal, markets for consumption (Katz 1996). 
Running Head: The Economic Deterioration of the Family

Consolidation: 1948-1966

The consolidation phase of the post-WWII SSA was a period of rising productivity, corporate profits and investments, low inflation and unemployment, and increasing real wages (Bowles, Gordon, and Weisskopf 1990). Accordingly, labor rights, employment for displaced workers, and pay equity expanded the capital-labor accord through the Landrum-Griffin Act, Manpower Development and Training Act, and the Equal Pay Act. Social Security Act amendments replaced ADC with Aid to Families with Dependent Children (AFDC) and, with the Federal Food Stamp Program, and Medicare and Medicaid health insurance programs for the aged and the poor, broadened the capitalist-state-citizen accord to previously excluded families. For the first time, poor mothers were given access to public assistance despite linking most benefits to community service or work obligations (Neubeck 2006). Provisions to support reproduction and socialization were built into the financial regime which separated commercial banking and insurance and extended interest rate caps on savings accounts. Finally, civil rights reforms created rent supplements and banned housing discrimination.

Despite these placative measures, the capitalist welfare state continually rebalanced private profitability with class compromises to maintain a surplus of lowwage labor. Families at the margins of the economic trajectory endured inequalities between capital and the lower-classes, between men and women, and between whites and non-whites. By 1966, the post-WWII accords provided a selective safety net for working- and middle-class families but challenged poor families to sufficiently perform their reproduction, socialization, and consumption roles within these contradictions of capital accumulation. 
Running Head: The Economic Deterioration of the Family

Decay: 1966-1979

SSA theorists argue that the decay of the post-WWII SSA occurred in two distinct sub-phases, the first from 1966 overlapping in 1973 with the second, which ended in 1979 (McDonough 2008). In the first sub-phase of decay, a race- and gender-based wage gap developed between the core manufacturing and industrial firms and secondary sector of marginalized labor propelling civil and welfare rights, black power, and feminist groups to demand economic justice by directly challenging the capital-labor and capitalist-state-citizens accords. A series of court rulings ended restrictive practices denying poor single mothers and families of color access to public assistance, stressing welfare rolls with a stark increase in recipients. In turn, capital could no longer depend on this marginal pool of low-wage labor and, in 1967 the Work Incentives Program (WIN) offered recipients voluntarily work opportunities in exchange for certain welfare benefits. Four years hence, amendments to the WIN program required recipients to work for welfare; directly benefitting capital, work was no longer voluntary for families.

The second sub-phase of decay was in part the result of strategic challenges to power relations between capital, the state, citizens, and families. Growing inflation and rising citizen unrest contributed to a severe recession in the early 1970s. Social spending was constrained at the same time capital cut wages, formally challenged union power, and relocated manufacturing to areas in the West, Southwest, and abroad where labor was weak (Piven and Cloward 1997). As a result, the fates of working and middle class families generated a dilemma for the federal government — sustain legitimacy by upholding the post-WWII SSA, or address the economic imperative for capital accumulation. The response signaled a shift in the conditions of existence for families. 
Running Head: The Economic Deterioration of the Family

Demands for consumption now outweighed demands for labor power. Capital, seeing corporate profits threatened by increased production costs and underconsumption, sought to stabilize their own reproduction and productivity by cutting wages and entire positions. Under these conditions, relief for families promoted consumption and managed demand with programs such as the supplemental food program for poor mothers. However, the most important program mirrored the profit motives of capital; by augmenting the annual earnings of low-income families, the Earned Income Tax Credit (EITC) incentivized low-wage work with much-needed means of consumption (Goldberg and Collins 2001).

In addition, with the rising number of dual-income households, access to and use of credit supported family consumption. The Equal Credit Opportunity Act banned discrimination in consumer loan and credit applications, providing for the first time, new means of consumption for non-whites and women, the Community Reinvestment Act obligated federally-insured depository institutions to invest in and serve their local populations, and a series of other consumer protections for credit reports, bankruptcy, and data disclosures legitimized credit and debt. Finally, the U.S. Supreme Court's 1978 Marquette v. First of Omaha ruling dismantled state interest rate caps opening the credit industry to use higher rates. With jobs and living wages becoming more elusive, the reproductive role of families waned and the capitalist welfare state sanctioned consumption with consumer credit and weakened financial regulations.

Prolonged Decay and Initial Exploration: 1979-1992

The 1980s marked the emergence of a new era of exploration, even as the old SSA continued to decay. Stagflation surfaced as minimal wage growth and productivity 
Running Head: The Economic Deterioration of the Family

regenerated low levels of investment and corporate profits. The exploration for institutional alternatives targeted the wide-spread underconsumption of families by attempting to reinvigorate capital accumulation with access to low-wage work, and banking and credit services. In this phase of "business ascendency," as the post-WWII SSA continued to decay, a liberal structure of institutional alternatives (Wolfson and Kotz 2010) explored means to promote accumulation and consumption through work, not welfare.

For example, the 1981 Omnibus Budget Reconciliation Act cut public assistance rolls while expanding mandatory WIN requirements, and subsequent amendments increased the age for full Social Security benefits while delaying cost of living increases. The 1988 Family Support Act replaced WIN with the JOBS Program, requiring women on welfare, even with children younger than three, to find work or enroll in training programs in exchange for basic benefits. Characteristic of the shift toward work for welfare-workfare- under this conservative liberalization, the EITC was simultaneously expanded and indexed to inflation.

Beginning with the 1980 repeal of regulations on state usury laws by the Depository Institutions Deregulation and Monetary Control Act, an environment of deregulation to promote capital mobility began to emerge. Subsequently, the Garn-St. Germain Act and Alternative Mortgage Transaction Parity Act eased mortgage interest rates and created a market that promoted household debt as mechanism for economic growth. Later legislation followed this trend; the Secondary Mortgage Market Enhancement Act lessened restrictions on mortgage-backed securities, the Tax Reform Act allowed for investments in these securities at different levels of risk, the Financial 
Running Head: The Economic Deterioration of the Family

Institutions Reform, Recovery and Enforcement Act opened the housing sector to private mortgage firms, and in 1992 the Federal Housing Enterprises Financial Safety and Security Act charged Fannie Mae and Freddie Mac to increase credit market access for underserved populations (Bostic and Lee 2009).

With a growing number of families necessarily seeking multiple incomes to supplement low wages and tax credits, easing mortgage market restrictions managed demand by arming financial capital with variable interest rates for consumer credit and mortgage loans, financing the most important family asset, their home.

Neoliberalism 1992-2007

The liberal institutional structure of the 1980s and early 1990s bridged the former period of long-term stable human relations with this phase of short-term contracts and private economic gain (Harvey 2005). Workfare became the hallmark of the capitalist welfare state as social security and welfare benefits were increasingly restricted. Most profound, 1996 “welfare reform” replaced AFDC with the Temporary Assistance for Needy Families program (TANF). TANF exemplifies neoliberalism’s mandate on shortterm, market-based contractual relations by obligating recipients to work despite increasing competition for even the most marginal jobs (Morgen et al. 2006). As norms of reproduction, socialization, and consumption were increasingly harder to meet, the capitalist welfare state fixated on accumulation, leaving middle-class, working-class, and poor families impaired to act on their own behalf.

Neoliberal financial deregulation progressed by lifting barriers restricting bank acquisition and merger activities. In 1999, the Graham-Leach-Bliley Act repealed GlassSteagall driving the growth of investment, commercial, and insurance banking 
Running Head: The Economic Deterioration of the Family

conglomerates. Later, the Commodity Futures Modernization Act expanded the activities of financial firms that, coupled with HOME Investment Partnerships for low-income housing, the American Homeownership and Economic Opportunity Act, and American Dream Downpayment Initiative, the promotion of homeownership and consumer debt continually invigorated the expansion of credit markets. Together, banks packaged these liabilities into derivatives_ credit- and mortgage-backed securities—-then sold, and resold, these debt obligations to willing investors (Kotz 2009).

Ultimately, the neoliberalization of the banking industry made it possible for financial capital to offer mortgage loans and consumer credit to risk-adverse, but willing families, historically discriminated against in housing and credit programs. These subprime markets allowed families to contribute to the circuit of capital by refinancing old loans or originating new obligations under expanding consumption norms catalyzed by an industry ready to benefit from these marginalized groups (Howell 2006). Finance capital balanced these risky loans with variable interest rates and potential profits by transferring the risk into securities markets.

Summarized in Table 1, this institutional analysis argues that changes to capitalist welfare state assistance, from cash welfare for the economically marginalized to consumer credit and low-wage labor tax credits, led in part to the deterioration of families after World War II. Underlying this shift is the changing primary relationship of the family as a capitalist institution from reproducing labor power to the consumption of goods and services. As languishing incomes exacerbated inequalities and the downward mobility of middle, working, and poor families, consumer credit supplied financial 
Running Head: The Economic Deterioration of the Family

assistance for the means of consumption, and ultimately the deterioration of families through unprecedented levels of consumer debt.

[Insert Table 1 About Here]

\section{Models and Variables}

Models and Expectations

The following expectations compare changes to public cash assistance and the rate of consolidation by financial capital as exogenous variables with four endogenous measures of family economic deterioration in the post-WWII period. Model 1 assesses total consumer credit outstanding; Model 2 estimates the ratio of household debt to disposable income; Model 3 measures the ratio of income inequality between the top 5 percent and bottom forty percent of families; and Model 4 estimates the ratio of household liabilities to their asset values.

Expectation \#1: As the family's primary institutional role shifts from reproduction to consumption, public cash assistance expenditures will have a negative relationship with outstanding consumer credit, as well as debt compared to disposable income, but a positive relationship with debt compared to assets.

Expectation \#2: Through the phases of the post-WWII SSA, changes in public cash assistance expenditures from welfare to workfare are expected to exacerbate a negative relationship with income inequalities between families.

Expectation \#3: Increased access to consumer credit through the deregulated financial sector contributes to family economic deterioration. 
Running Head: The Economic Deterioration of the Family

\section{Variables}

National U.S. annual time-series data on public assistance, family deterioration, financial deregulation, and unemployment begin with the 1948 consolidation of the postWWII SSA in the United States through the start of the recession in December $2007 .^{2}$ Independent Variables

Total public cash assistance expenditures on relief is the sum of capitalist welfare state expenditures through ADC/AFDC, TANF, EITC, and historical Aid to the Aged, Blind, Permanently and Totally Disabled, General Assistance, and Supplemental Security Income (SSI) programs.

The number of total unassisted mergers of commercial banks provides a gauge of the deregulated finance industry's impact on the circuit of capital. As a measure of the pace of financialization, unassisted merger and acquisition activities promote profits by building a geographically broad clientele, constraining competition, and diversifying financial products (Spiegel and Gart 1996).

The not seasonally adjusted unemployment rate is included to control for labor market fluctuations and business cycles.

Dependent Variables

For Model 1, the total consumer credit outstanding is the level of new and ongoing private credit obligations for consumption and subsistence, and incidence of debt poverty (Pressman and Scott 2009b).

In Model 2, the household debt ratio compares the sum of new and outstanding home mortgage and consumer credit loans assumed by families with their ability to pay down these obligations through their disposable personal income. Household credit 
Running Head: The Economic Deterioration of the Family

liabilities allow families to supplement or replace income and guarantee some level of purchasing power and effective demand (Blundell, Pistaferri, and Preston 2008). Disposable personal income is the money available to households after taxes and transfers are deducted from their annual income.

The liabilities-to-assets ratio in Model 4 compares outstanding household liabilities, as above, to the total current value of their assets by replacing disposable personal income with the total value of the family home and consumer durable goods. This ratio measures the relative change in family debt-to-assets, an indicator of the economic imbalance of families described as being “underwater” (Goodman 2009; Pressman and Scott 2009a).

For Model 3, family income inequality compares changes in the aggregate share of total income going to the top 5 percent of families to that going to the bottom 40 percent. Often, changes in family income are measured for the "middle class," however little agreement exists on a definition for this fluid demographic (Danziger and Haveman 2001). Juxtaposing the economic elite with the working poor and impoverished reflects relative changes in the gap between the most affluent and most vulnerable families.

\section{Results}

Table 2 presents the results of the four multivariate time-series regression analyses which demonstrate, to varying degrees, the relationship between family economic deterioration and changes in the capitalist welfare state through the progression of the post-WWII SSA. For each model, estimates of the unstandardized slope and standard coefficients (in parentheses), the processes responsible for autocorrelation in the residuals (error), the adjusted- $R^{2}$ values and y-intercepts (constant), and the Chow 
Running Head: The Economic Deterioration of the Family

breakpoint tests (Chow LR Test) are provided. ${ }^{3}$ These observed relationships are not causal but correlational, and show the pattern of historically-contingent effects, most evident by considering the Chow breakpoint tests were the null hypothesis of stability across SSA phases is rejected for each model.

[Insert Table 2 About Here]

The first empirical expectation anticipated that as the family’s primary institutional role shifts from reproduction to consumption, public cash assistance expenditures will have a negative relationship with consumer credit and the household debt ratio, but have a positive relationship with debt to assets. The pattern of effects for total consumer credit outstanding (Model 1), the household debt ratio (Model 2), and the liabilities-to-assets ratio (Model 4) provide support for this expectation. The standardized coefficients in Model 1 indicate that this relationship is very strong during both decay sub-phases ( $\beta=-.867$ and $\beta=-.837$, respectively), and in the decay 2 sub-phase in Model $2(\beta=-.858)$. In the decay 1 sub-phase, provision of public cash assistance was expanded to support the reproductive role of families in response to rising social unrest exposing the contradictions of the post-WWII SSA. However, swollen relief rolls put fiscal pressure on the capitalist welfare state and catalyzed popular backlash against welfare spending. When economic growth slowed, and more families demanded relief, the means of consumption began to shift in the second decay sub-phase through legislation that opened consumer lending to minorities and women, and that promoted low-wage work with the EITC.

In the prolonged decay and initial exploration phase, and amplified in the neoliberalism phase, increased access and use of credit mechanisms sustained the needs 
Running Head: The Economic Deterioration of the Family

of families to access means of consumption, but their expenditures on goods and services brought little in return to their net worth. In Model 4, the expected pattern of effects in the latter two SSA phases ( $\beta=.540$ and $\beta=1.096^{4}$, respectively) demonstrate how, concomitant continued policy shifts promoting workfare and consumer debt, liabilities outpaced growth in the value of assets, strengthening the correlation between consumption and the economic deterioration of families. Together with the effects in Models 1 and 2, trading public welfare for low-wage tax credits is a strong predictor of increasing consumer debt.

In the consolidation phase, middle-class families covered by the post-WWII SSA accords translated to a positive weak effect of cash assistance on outstanding consumer credit $(\beta=.354)$. This finding, though not outlined in the empirical expectations, is supported by SSA theory where the use of credit was purposeful in a stable institutional environment conducive for consumer confidence and capital accumulation (Kotz 2009).

The estimates from Model 3 provide support for the second expectation that anticipated that changes in public cash assistance expenditures exacerbate inequalities between families. The negative relationship between public cash assistance and income inequality in the second decay sub-phase $(\beta=-.923)$ and in neoliberalism $(\beta=-.781)$ reinforces the correlation between the promotion of low-wage employment and growing social inequalities. In the first sub-phase of decay, when the balance of public cash assistance expenditures is dominated by publicly financed cash welfare, inequalities between families are unchanged. However, in the following sub-phase, the unstandardized coefficient shows that for an annual decrease of \$1 billion in cash assistance, there is an increase of .4 percent in income inequality. The widening divide 
Running Head: The Economic Deterioration of the Family

between the top 5 percent and bottom 40 percent of the family income stratification, despite a growing number of dual-income households, accelerated as tax credits were unable to offset low-wages. In the neoliberalism phase, this effect is greater, where income inequality is increased by 1.5 percent for each $\$ 1$ billion decrease in public assistance spending.

Finally, across all four models, the third expected relationship between the rate of change in the number of commercial bank mergers and the deterioration of families is observed during particular historical moments. Expected across all SSA phases, and weakly corroborated in Model $1(\beta=.108)$ and Model $3(\beta=.172)$, significant positive effects are more prevalent in the consolidation period of rapid economic growth from 1948-1966 and in the neoliberalism phase from 1993-2007 as the financial sector responded to rapid economic policy changes. In the consolidation phase, low but significant increases in the rate of bank mergers aided the growth in the use of credit by the middle class (Model 1: $\beta=.377$; Model 4: $\beta=.449$ ). For example, still regulated by the post-WWII regime, credit was low risk and relatively safe and offered to families covered by the capital-labor accord; thus, for every proportional increase in bank mergers, total consumer credit outstanding increased by $\$ 29.1$ billion. In addition, as banks continued to merge in neoliberalism, Model 3 shows that for a proportional change in the rate of bank mergers, the proportion of income going to the top 5 percent and the bottom 40 percent increased by 18.0 percent $(\beta=.346)$. Model 1 also supports this expectation where, in neoliberalism, outstanding consumer credit increased by $\$ 122.36$ billion for every proportional change in the rate of bank mergers $(\beta=.433)$. 
Running Head: The Economic Deterioration of the Family

However, the significant negative relationship between the rate of mergers and household debt during neoliberalism in Model 2 was unexpected $(\beta=-.260)$. Here, the increased rates of bank mergers promoted access to consumer credit to purchase homes and durable goods, activities that provided capital with funds for reinvestment from interest payments on obligations. As personal savings rates fell, eroding disposable incomes increased debt and slowed merger activities. Another reason for this relationship, illuminated by the nonsignificant effect found in the neoliberalism phase in Model 4, where the rate of mergers promoted consumption, but for goods and services that brought little increase in the net worth of families. The absence of a significant effect may correspond to the need of the financial sector for effective demand, but less on the long-term value of household assets.

\section{Discussion}

These time-series models offer patterns of theoretically-informed effects conditioned by the macro-institutional analysis of the family as an institution in the postWWII SSA in the United States. The economic security of families was established through the New Deal by stabilizing working conditions and compensation, the social safety net, and the banking industry. These institutions also linked key family reproduction, socialization, and consumption roles to the capital accumulation as the benefits and wages of middle-class breadwinners and supported a stable circuit of capital.

Over the next four decades, the contradictions of the New Deal between affluence and poverty exposed how families excluded from the post-WWII SSA languished. As the economy stalled in the early 1970s, capital's attempts to maintain profitability to the detriment of the working and middle classes generated a dilemma for the federal 
Running Head: The Economic Deterioration of the Family

government between capital accumulation and the livelihood of citizens. Subsequently, the negative relationship between public cash assistance and family economic deterioration was observed during the decay of the post-WWII SSA, particularly in the second sub-phase from 1974-1979. Here, to support accumulation, barriers to consumer credit fell and public cash assistance began transitioning to private work-based relief.

From the early 1980s through 2007, financial deregulation, social welfare retrenchment, emerging low-wage workfare, and expanding access to consumer credit promoted the new norms of self-sufficiency and personal responsibility. For the capitalist welfare state, economic growth was linked to the consumption role of families, but who became insolvent long before the onset of the "Great Recession”. Beginning in 1993, for every billion dollars annually cut from public cash assistance expenditures the gap between the rich and the poor expanded by 1.5 percent; the top 5 percent of families clearly benefited from the financialization of the capitalist welfare state.

The anticipated positive effects for unassisted bank mergers are most prevalent in the consolidation and neoliberalism phases. Increasing socioeconomic inequality reinforced by consumer borrowing meant that families tapped their savings to pay down debts. When banks merged and developed new means to exploit families as consumers, including loans against the value of their only wealth-generating asset, the family home, the proportional rate of mergers created a \$122.4 billion increase annually in total consumer credit outstanding. When defaults on these financial obligations increased, over-leveraging the family burst the credit and housing markets and the economic deterioration of the family proved detrimental to financial capital. 
Running Head: The Economic Deterioration of the Family

\section{Limitations and Implications}

Though combining multiple modes of inquiry provide provisional and correlational evidence for historically-contingent relationships, further research is needed. For example, the institutional analysis discussed the capitalist-state-citizen accord and capital-labor accord, as well as the financial regulatory regime; however, the time-series models focus on the relationships between the family, the state, and capital. The family household provides critical support to capital and labor power (Kotz 1994), but this relationship has traditionally been anchored by SSA theory in the capital-labor accord; these models refocus the family as an institution in the capitalist-state-citizen accord. To strengthen these models, a measure of labor's strength relative to capital that impacts the economic wellbeing of families, such as the cost of the risk labor takes in escalating conflicts with management or the decline in union membership, could be incorporated (Bowles, Gordon, and Weisskopf 1989).

A second substantive limitation is the impact of taxes on the economic wellbeing of families. For example, low-wage earners, as a percentage of total income, lose more to taxes both upfront in the form of payroll taxes and through sales tax and federal excise taxes often passed on to consumers by businesses (Hassett and Moore 2006). Moreover, taxes levied on capital gains from the economic investments of affluent families have traditionally redistributed income from the top to the bottom of the income bracket through social spending. However, cuts to capital gains taxes, promoted as a means to stimulate economic growth, redistribute income upward intensifying income inequalities (Boyer 2010). In future work should incorporate a measure of personal taxes for both the bottom and top of the family income distribution. 
Running Head: The Economic Deterioration of the Family

Despite these limitations, this analysis details attempts by the capitalist welfare state of the post-WWII United States to negotiate contradictions between the economic conditions for the reproduction of the family and for the reproduction of capital, leading up to the latest capitalist crisis. Through the phases of the post-WWII SSA, the family's primary contribution to the circuit of capital shifted from reproduction to consumption as the strategic balance of welfare for capital and welfare for families defined the conditions of existence. This change, from a publicly provided safety net for social reproduction to private self-sufficient consumption, underscores the economic deterioration of families in the name of capital accumulation. 
Running Head: The Economic Deterioration of the Family

\section{Data Appendix}

\section{Independent Variables}

Total Public Cash Assistance Expenditures are the sum total payments for Aid to the Aged, Blind, Permanently and Totally Disabled, and General Assistance. Data for 1960-1973 come from Carter et al. (2006: Bf634, Bf635, Bf636, Bf638); 1948-1949, 1951-1954, and 1956-1959 were missing from later estimates, therefore early estimates were used (Carter et al. 2006: Bf621, Bf622, Bf623, Bf625).

Aid to Dependent Children (ADC) and Aid to Families with Dependent Children (AFDC) expenditure series 1960-1997, come from Carter et al. (2006: Bf634, Bf635, Bf636, Bf638); 1948-1949, 1951-1954, 1956-1959 were missing from the later estimates, therefore early estimates for 1948-1959 were used (Carter et al. 2006: Bf621, Bf622, Bf623, Bf625).

Temporary Assistance for Needy Families (TANF) expenditures for 1998-2007 were obtained from the Administration for Children and Families (2009: Table F, Line 5 for selected years).

Total Supplemental Security Income (SSI) payments, which replaced earlier Aid to the Aged, Blind, Disabled and General Assistance programs in 1974, were obtained for 1974-1998 from Carter et al. (2006: Bf600 and Bf601); data for 1999-2007 come from the Social Security Administration (2008: Table 7.A4; 2010: Table 7.A4).

Earned Income Tax Credit (EITC) payments, first implemented in 1975, are reported in the Internal Revenue Service Statistics of Income data (IRS-SOI); data for 1975-1994 come from the Tax Policy Institute (2011) and for 1995-2007 from the IRSSOI (2010, selected years). 
Running Head: The Economic Deterioration of the Family

The total number of unassisted commercial bank mergers is the annual sum of unassisted voluntary mergers, consolidations or absorptions of two or more institutions reported by the Federal Deposit Insurance Corporation (2010).

The Bureau of Labor Statistics’ (2010) not seasonally adjusted unemployment rate, controlling for business cycle effects, is the percentage of the total labor force 16 years and older without jobs but available and actively seeking work, or on temporary layoff even if not actively seeking employment.

\section{Dependent Variables}

Total consumer credit outstanding is the annual (calendar year) average of monthly reported levels of not seasonally adjusted outstanding consumer credit at month’s end (Federal Reserve Board of Governors 2010b).

Total household liabilities come from the Federal Reserve’s Flow of Funds Balance Sheet of Households and Nonprofit Organizations (2010a: Table B. 100) and are the sum of home mortgage (line 33) and consumer credit (line 34) balances outstanding at the end of the calendar year. Total household assets are the sum of the value of the household (line 4) and consumer durable goods at current replacement costs (line 7).

Disposable personal income (Bureau of Economic Analysis 2010: Table 2.1, Line 26) is the annual average of seasonally adjusted quarterly income from wage compensation and supplements from employers, and other forms of income, less contributions to governmental insurance programs and taxes. The use of disposable personal income controls for wage levels, changes in population, price fluctuations, and the general volume of economic activity (Teplin 2001). 
Running Head: The Economic Deterioration of the Family

Together, the household debt ratio is the total household liabilities per dollar of disposable personal income. Other measures comparing debt to income exist (Bucks et al. 2009), but do not for the earliest years needed for this analysis. The liabilities-toassets ratio is the total household liabilities per dollar of the total household assets.

Family Income Inequality is the simple division of the proportion of aggregate family income of the bottom two quintiles into the top 5 percent across all families as reported by the U.S. Census Bureau (2009).

\section{Time-Series Analysis Procedures}

The form of each univariate series was determined first by examining time-series plots across the entire post-WWII SSA and within each of the identified sub-phases. Next, univariate descriptive statistics, Jarque-Bera tests for normality, examination of correlograms and Ljung-Box Q-statistics to assess autocorrelation and nonstationarity in the mean of each series, and performance of Dickey-Fuller and Augmented Dickey-Fuller unit root tests were conducted (for a description of these tests see Cromwell, Labys, and Terraza 1994). If the null hypothesis of a unit root was not rejected $(p<0.05)$, the series was differenced appropriately and tests for normality and autocorrelation were repeated until the series was stationary. A final univariate model was estimated with autoregressive and/or moving average parameters to correct for these processes.

Next, a Chow breakpoint stability test examined historical stability by comparing the full post-WWII series model with separate models for each post-WWII SSA phase under the null hypothesis that each does not vary across these theoretically derived phases of economic growth and decline; stability was rejected when the likelihood ratio statistic is significant $(p<0.10)$, supporting the hypothesis of historical contingency. 
Running Head: The Economic Deterioration of the Family

Separate period-specific univariate models were estimated to determine their proper form and tested for normality, stationarity, and independence, and accepted when $Q$-statistics in the first 2 lags failed to reject the null hypothesis of stationarity $(p<0.05) .^{5}$

Next, each measure of family economic deterioration was regressed separately on each independent variable to determine bivariate relationships across and within SSA phases. Autocorrelation and partial autocorrelation processes were diagnosed in the residuals, correlograms and Ljung-Box $Q$-statistics for nonstationarity were consulted, and if independent errors in the residuals were rejected $(p<.05)$, autoregressive and/or moving average parameters were added to correct for these processes. The bivariate models were then re-estimated and accepted when $Q$-statistics and Jarque-Bera tests signaled stationarity and normality. The final model was tested with the White's test for heteroskedasticity under the null hypothesis of homoskedasticity $(p<.05)$; if needed, the model was re-estimated using White's correction to produce robust standard error estimates and t-test statistics. Finally, a Chow breakpoint test for each bivariate model across phases of the post-WWII SSA rejected the null hypothesis of stability $(p<.10)$, showing a significant difference between each family economic deterioration variable and each predictor. ${ }^{6}$

Multivariate models were estimated first through a null model of bank mergers and unemployment, then by adding public cash assistance. The residuals of these models were assessed for stationarity through Q-statistics, Jarque-Bera tests for normality, White's tests for heteroskedasticity, and Chow breakpoint tests for stability. Corrections were made until the residuals were stationary, normally distributed, and corrected for any heteroskedasticity. 
Running Head: The Economic Deterioration of the Family

Additional tests on models with multiple independent variables were conducted to assess the stability of slope coefficients and presence of multicollinearity. While estimates remain robust with multicollinearity and inflated standard errors, it becomes more difficult to reject the null hypothesis of no relationship (Agresti and Finlay 2008). The variance inflation factor (VIF) assessed the impact of highly correlated predictor variables on the variance of the parameter estimates. Collinearity was rejected when the VIF was greater than 2.5 (Allison 1999) and, to determine if estimates were impacted, models were re-estimated excluding one collinear variable.

Due to the close historical relationship between public assistance and unemployment (Piven et al. 2002), moderate multicollinearity within the neoliberal phase (VIF values range between 2.85 to 3.81 ) exists, but does not within other phases or across the full post-WWII SSA.

Second, the condition index is a measure of the numerical stability of slope coefficients affected by collinearity. Unstable slope estimates are not reliable predictors of relationships between the affected independent and dependent variables. All models in this analysis, even those showing moderate VIF values greater than 2.5 possess condition indices less than the cut-off of 30.0 (Belsley 1991), supporting the numerical stability of all estimates.

Finally, each measure of family economic deterioration was regressed on public cash assistance expenditures, the unassisted mergers of commercial banks, and the not seasonally adjusted unemployment rate across the full post-WWII SSA and each subphase. Model diagnostics followed the same procedures as above, including rejecting independent errors in the residuals through autocorrelation and partial autocorrelations 
Running Head: The Economic Deterioration of the Family

functions and associated Ljung-Box $Q$-statistics $(p<0.05)$. In the presence of serial correlation, autoregressive and/or moving average parameters were added to the model until stationarity was achieved. Normality of the residuals was tested using the JarqueBera test, and the White's test for heteroskedasticity was performed. Finally, the Chow breakpoint test rejected model stability across the phases of the post-WWII SSA $(p<.10)$ thus full post-WWII and SSA phase-specific results for the relationships between public assistance and family economic deterioration are provided. 
Running Head: The Economic Deterioration of the Family

Table 1: Institutional Conditions Across Phases of the Post-WWII SSA

\begin{tabular}{|c|c|c|c|c|}
\hline \multirow[b]{2}{*}{ SSA Phase } & \multicolumn{3}{|c|}{ Institutional Conditions } & \multirow[b]{2}{*}{ Family Conditions of Existence } \\
\hline & $\begin{array}{l}\text { Capitalist-State- } \\
\text { Citizen Accord }\end{array}$ & $\begin{array}{c}\text { Capital-Labor } \\
\text { Accord }\end{array}$ & Financial Regime & \\
\hline $\begin{array}{r}\text { Consolidation } \\
1948-1966\end{array}$ & $\begin{array}{l}\text { Cash Assistance and } \\
\text { Capitalist Welfare State } \\
\text { Provisions } \\
\text { - Social Security } \\
\text { Expansion } \\
\text { - AFDC Expansion } \\
\text { - Civil Rights Reforms } \\
\text { - Community Action } \\
\text { Agencies }\end{array}$ & $\begin{array}{l}\text { Industrial } \\
\text { Democracy and Full } \\
\text { Employment } \\
\text { - Landrum-Griffin } \\
\text { - MDTA } \\
\text { - Affirmative } \\
\text { Action and Equal } \\
\text { Pay }\end{array}$ & $\begin{array}{l}\text { Fiscal Stabilization } \\
\text { and Urban Support } \\
\text { - Low-Income } \\
\text { Housing Programs } \\
\text { - Urban } \\
\text { Redevelopment } \\
\text { Initiatives } \\
\text { - Regulation Q }\end{array}$ & $\begin{array}{l}\text { Structural: } \\
\text { - Normative family promotes } \\
\text { stability } \\
\text { Institutional: } \\
\text { - Social Reproduction } \\
\text { Economic: } \\
\text { - Rising median family incomes } \\
\text { - Decreasing poverty rates } \\
\text { - Unemployment less than } 4 \% \\
\text { - Low, but growing debt obligations }\end{array}$ \\
\hline $\begin{array}{r}\text { Decay } 1 \\
1966-1973\end{array}$ & $\begin{array}{l}\text { Increase in Assistance; } \\
\text { First Work Mandates } \\
\text { - Work Mandated for } \\
\text { Public Assistance } \\
\text { (WIN) } \\
\text { - Jobs Training } \\
\text { Programs (CEP/JOBS) } \\
\text { - SSI Established }\end{array}$ & $\begin{array}{l}\text { Employability and } \\
\text { Jobs Training } \\
\text { - CETA } \\
\text { - Equal } \\
\text { Employment and } \\
\text { Civil Rights } \\
\text { Amendments }\end{array}$ & $\begin{array}{l}\text { Mortgage Promotion } \\
\text { and Credit Protection } \\
\text { - Fannie Mae and } \\
\text { Secondary } \\
\text { Mortgage Markets } \\
\text { - Consumer } \\
\text { Protection } \\
\text { - Fair Credit } \\
\text { Regulations }\end{array}$ & $\begin{array}{l}\text { Structural: } \\
\text { - Civil rights and market diversity; } \\
\text { - Rise of single-parent mothers } \\
\text { Institutional: } \\
\text { - Social Reproduction } \\
\text { Economic: } \\
\text { - Slowly rising median incomes } \\
\text { - Poverty rates under } 10 \% \\
\text { - Unemployment near } 5 \% \\
\text { - Stable consumer spending }\end{array}$ \\
\hline $\begin{array}{r}\text { Decay } 2 \\
1973-1979\end{array}$ & $\begin{array}{l}\text { Enforcement of Welfare } \\
\text { and Work Provisions } \\
\text { - Supplemental Food } \\
\quad \text { Program (WIC) } \\
\text { - EITC }\end{array}$ & & $\begin{array}{l}\text { Credit and Debt for } \\
\text { the Middle Class } \\
\text { - Lending as } \\
\text { Community } \\
\text { Reinvestment } \\
\text { - Fair Credit and } \\
\text { Debt Regulations, } \\
\text { cont. } \\
\text { - Bankruptcy } \\
\text { Protections } \\
\text { - Supreme Court's } \\
\text { Marquette Decision }\end{array}$ & $\begin{array}{l}\text { Structural: } \\
\text { • Women entering workforce; } \\
\text { • Dual income households } \\
\text { Institutional: } \\
\text { - Reproduction waning; } \\
\text { Consumption promoted } \\
\text { Economic: } \\
\text { - Stagnating median incomes } \\
\text { - Poverty rates over 9\% } \\
\text { - 6\% Unemployment } \\
\text { - Consumer credit increases }\end{array}$ \\
\hline $\begin{array}{r}\text { Prolonged } \\
\text { Decay and } \\
\text { Initial } \\
\text { Exploration } \\
\text { 1979-1992 }\end{array}$ & $\begin{array}{l}\text { Growth of Workfare and } \\
\text { Welfare Retrenchment } \\
\text { - Welfare Roll } \\
\text { Reductions; Spending } \\
\text { Cuts } \\
\text { - Workfare through } \\
\text { FSA and JOBS }\end{array}$ & $\begin{array}{l}\text { Business } \\
\text { Ascendancy } \\
\text { - Liberalization of } \\
\text { Labor Relations } \\
\text { - Declining } \\
\text { Unionization }\end{array}$ & $\begin{array}{l}\text { Financial } \\
\text { Deregulation } \\
\text { - Easing Credit } \\
\text { Controls } \\
\text { - Tax Reforms to } \\
\text { Promote Mortgage } \\
\text { Debt } \\
\text { - Federal Housing } \\
\text { Assistance and } \\
\text { GSE Expansion }\end{array}$ & $\begin{array}{l}\text { Structural: } \\
\text { - Rebalancing labor and household } \\
\text { norms } \\
\text { Institutional: } \\
\text { - Consumption } \\
\text { Economic: } \\
\text { - Flat median incomes } \\
\text { - Poverty rising to } 12 \% \\
\text { - } 7 \% \text { unemployment } \\
\text { - Growing household debt }\end{array}$ \\
\hline $\begin{array}{r}\text { Neoliberal } \\
\text { Exploration } \\
1992-2007\end{array}$ & $\begin{array}{l}\text { End of Cash Assistance } \\
\text { and Institutionalization } \\
\text { of Workfare } \\
\text { - Welfare Reform and } \\
\text { TANF } \\
\text { - ADDI }\end{array}$ & & $\begin{array}{l}\text { Fiscal Mechanisms } \\
\text { - Financial Product } \\
\text { Innovation } \\
\text { - Relaxing Barriers } \\
\text { between Financial } \\
\text { Institutions } \\
\text { - Bankruptcy Reform } \\
\text { - Growth in } \\
\text { Subprime Markets }\end{array}$ & $\begin{array}{l}\text { Structural: } \\
\text { - Financial capacity promoted } \\
\text { despite labor market status } \\
\text { Institutional: } \\
\text { - Deregulated Consumption } \\
\text { Economic: } \\
\text { - Slow median income growth } \\
\text { - Poverty rate near } 10 \% \\
\text { - Unemployment between } 4-7 \% \\
\text { - Rapid growth in debt obligations }\end{array}$ \\
\hline
\end{tabular}


Running Head: The Economic Deterioration of the Family

Table 2: Models of Family Economic Deterioration

\begin{tabular}{|c|c|c|c|c|c|c|}
\hline & $\begin{array}{c}\text { Full SSA } \\
1948-2007\end{array}$ & $\begin{array}{c}\text { Consolidation } \\
\text { 1948-1966 }\end{array}$ & $\begin{array}{c}\text { Decay } 1 \\
1967- \\
1973\end{array}$ & $\begin{array}{c}\text { Decay } 2 \\
1974- \\
1979\end{array}$ & $\begin{array}{l}\text { Prolonged } \\
\text { Decay and } \\
\text { Initial } \\
\text { Exploration } \\
\text { 1980-1992 } \\
\end{array}$ & $\begin{array}{c}\text { Neoliberalism } \\
\text { 1993-2007 }\end{array}$ \\
\hline \multicolumn{7}{|c|}{$\begin{array}{l}\text { Model 1, Total Consumer Credit Outstanding } \\
\end{array}$} \\
\hline Public Cash & -1.141 & $7.543+$ & $-7.590 *$ & $-5.981^{*}$ & -2.440 & 1.369 \\
\hline Assistance & $(-.088)$ & $(.354)$ & $(-.867)$ & $(-.837)$ & $(-.160)$ & $(.133)$ \\
\hline Unassisted & $23.757 * *$ & $29.055^{*}$ & -10.855 & 2.404 & 22.132 & $122.357 * *$ \\
\hline Mergers & $(.108)$ & $(.377)$ & $(-.088)$ & $(.013)$ & $(.101)$ & $(.433)$ \\
\hline Unemployment & $\begin{array}{c}-11.337 * * \\
(-.335)\end{array}$ & $\begin{array}{c}-4.712+ \\
(-.319)\end{array}$ & $\begin{array}{c}13.451+ \\
(.503)\end{array}$ & $\begin{array}{c}-17.009+ \\
(-.414)\end{array}$ & $\begin{array}{c}-15.078 \\
(-.318)\end{array}$ & $\begin{array}{c}-.869 \\
(-.015)\end{array}$ \\
\hline Constant & $107.751^{* *}$ & $45.354 *$ & -5.388 & $149.020+$ & 127.247 & 10.498 \\
\hline Error & $\begin{array}{l}\mathrm{AR}(1) \\
\mathrm{MA}(1)\end{array}$ & MA(1) & WNR & WNR & $\operatorname{AR}(1)$ & $\begin{array}{l}\mathrm{AR}(1) \\
\mathrm{AR}(2)\end{array}$ \\
\hline $\begin{array}{l}\text { Adj. } \mathrm{R}^{2} \\
\text { Chow LR Test }\end{array}$ & $\begin{array}{c}.686 \\
52.401^{* *} \\
\end{array}$ & .498 & .681 & .842 & .273 & .696 \\
\hline \multicolumn{7}{|c|}{ Model 2, Household Debt Ratio } \\
\hline Public Cash & .000 & .002 & -.003 & $-.003^{*}$ & .001 & .000 \\
\hline Assistance & $(-.050)$ & $(.181)$ & $(-.556)$ & $(-.858)$ & $(.174)$ & $(-.067)$ \\
\hline Unassisted & .006 & $.028 *$ & .006 & .010 & .005 & $-.039+$ \\
\hline Mergers & $(.057)$ & $(.465)$ & $(.082)$ & $(.112)$ & $(.065)$ & $(-.260)$ \\
\hline Unemployment & $\begin{array}{c}-.001 \\
(-.041)\end{array}$ & $\begin{array}{l}.001 \\
(.068)\end{array}$ & $\begin{array}{c}.007 \\
(.453)\end{array}$ & $\begin{array}{c}-.005 \\
(-.263)\end{array}$ & $\begin{array}{l}-.005 \\
(-.296)\end{array}$ & $\begin{array}{l}.021^{*} \\
(.695)\end{array}$ \\
\hline Constant & .020 & .014 & -.028 & .051 & .039 & -.068 \\
\hline Error & $\operatorname{AR}(1)$ & WNR & WNR & WNR & $\operatorname{AR}(1)$ & $\operatorname{AR}(1)$ \\
\hline Adj. $R^{2}$ & .410 & .134 & .000 & .896 & .117 & .585 \\
\hline Chow LR Test & $32.273 *$ & & & & & \\
\hline \multicolumn{7}{|c|}{ Model 3, Income Inequality } \\
\hline Public Cash & .000 & .002 & .003 & $-.004^{*}$ & .001 & $-.015^{*}$ \\
\hline Assistance & $(.011)$ & $(.058)$ & $(.269)$ & $(-.923)$ & $(.133)$ & $(-.781)$ \\
\hline Unassisted & $.042+$ & .061 & .060 & -.034 & .024 & $.180 *$ \\
\hline Mergers & $(.172)$ & $(.278)$ & $(.360)$ & $(-.308)$ & $(.172)$ & $(.346)$ \\
\hline Unemployment & $\begin{array}{l}.012^{* *} \\
(.315)\end{array}$ & $\begin{array}{l}.021 * \\
(.493)\end{array}$ & $\begin{array}{l}.009 \\
(.250)\end{array}$ & $\begin{array}{l}-.007 \\
(.294)\end{array}$ & $\begin{array}{c}.008 \\
(.256)\end{array}$ & $\begin{array}{c}.104^{*} \\
(1.003)\end{array}$ \\
\hline Constant & $-.060 *$ & $-.112 *$ & -.050 & -.029 & -.036 & $-.491+$ \\
\hline Error & WNR & WNR & WNR & WNR & WNR & WNR; \# \\
\hline Adj. $\mathrm{R}^{2}$ & .100 & .242 & .000 & .630 & .000 & .328 \\
\hline Chow LR Test & $24.106+$ & & & & & \\
\hline \multicolumn{7}{|c|}{ Model 4, Liabilities-to-Assets Ratio } \\
\hline Public Cash & $.002 *$ & .002 & -.001 & .001 & $.003+$ & $.010 * *$ \\
\hline Assistance & $(.267)$ & $(.113)$ & $(-.273)$ & $(.229)$ & $(.540)$ & $(1.096)$ \\
\hline Unassisted & .013 & $.050 *$ & -.032 & .040 & .003 & -.032 \\
\hline Mergers & $(.090)$ & $(.449)$ & $(-.519)$ & $(.419)$ & $(.040)$ & $(-.132)$ \\
\hline Unemployment & $\begin{array}{c}-.004 \\
(-.197)\end{array}$ & $\begin{array}{c}.000 \\
(-.017)\end{array}$ & $\begin{array}{l}.007+ \\
(.502)\end{array}$ & $\begin{array}{c}-.012 \\
(-.607)\end{array}$ & $\begin{array}{l}.001 \\
(.034)\end{array}$ & $\begin{array}{l}-.037 * \\
(-.762)\end{array}$ \\
\hline Constant & $.039+$ & .041 & -.044 & .074 & -.003 & $.194+$ \\
\hline Error & $\operatorname{AR}(1)$ & WNR & $\operatorname{AR}(1)$ & WNR & WNR & WNR \\
\hline Adj. $R^{2}$ & .267 & .055 & .454 & .356 & .040 & .263 \\
\hline Chow LR Test & $30.093+$ & & & & & \\
\hline
\end{tabular}




\title{
Running Head: The Economic Deterioration of the Family
}

\begin{abstract}
Notes
${ }^{1}$ The phases of the post-WWII SSA are provided in Table 1 . Theoretical disagreement exists on whether a newly consolidated SSA formed in the early 1990s; this analysis considers the most recent phase a prolonged neoliberal exploration (McDonough 2008).

${ }^{2}$ Detailed definitions and sources for each variable are provided in the Data Appendix.

${ }^{3}$ Time-series model building procedures are described in detail in the Data Appendix

${ }^{4}$ Inflated standard betas are expected due to micronumerocity within short time series (Goldberger 1991) and, shaped by historically-contingent shifts in social conditions, enlarged variances and moderate multicollinearity during the decay 2 and neoliberalism phases exist. Strong statistical results in the presence of micronumerocity are favorable, as is the case here. Where traditional practices may outright dismiss such estimates, it is more prudent to interpret effects within historical conditions (Griffin 1992).
\end{abstract}

${ }^{5}$ The final form of each series is as follows: public cash assistance is first-differenced; total consumer credit outstanding is first-differenced except in neoliberalism where it is second-differenced; the household debt ratio is first-differenced; income inequality is first-differenced; the liabilities-to-assets ratio is firstdifferenced; the total unassisted mergers of commercial banks is the first-difference of the natural log; and unemployment is in levels.

${ }^{6} \mathrm{~A}$ p-value of .10 is used rather than the customary .05 because the number of degrees of freedom in the separate SSA phase models is low relative to the number of predictor variables and likely to result in large standard error estimates. In addition, these are not sample data; significance tests are used to rule out chance findings rather than to draw inferences about a population. 
Running Head: The Economic Deterioration of the Family

\section{References}

Administration for Children and Families. 2009. "TANF Financial Data." U.S.

Department of Health and Human Services Washington, D.C.

http://www.acf.hhs.gov/programs/ofs/data/index.html.

Agresti, A., and Finlay, B. (2008). Statistical Methods for the Social Sciences. 4th ed. Upper Saddle River, NJ: Prentice-Hall.

Allison, P. D. (1999). Multiple Regression: A Primer. Thousand Oaks, CA: Pine Forge Press.

Almond, B. (2006). The Fragmenting Family. Oxford, England: Clarendon.

Barba, A., and Pivetti, M. (2009). "Rising Household Debt: Its Causes and Macroeconomic Implications - A Long-Period Analysis." Cambridge Journal of Economics 33(1): 113-37.

Becker, G. S. (1991). A Treatise on the Family: Enlarged Edition. Cambridge, MA: Harvard University Press.

Belsley, D. A. (1991). "A Guide to using the Collinearity Diagnostics." Computational Science in Economics and Management 4(1): 33-50.

Blank, R. M., and Barr, M. S., editors. 2009. Insufficient Funds: Savings, Assets, Credit, and Banking among Low-Income Households. New York: Russell Sage Foundation.

Blundell, R., Pistaferri, L. and Preston, I. (2008). "Consumption Inequality and Partial Insurance." American Economic Review 98(5): 1887-921.

Bostic, R. W., and Lee, K. O. (2009). "Homeownership: America's Dream?" In Insufficient Funds: Savings, Assets, Credit, and Banking among Low-Income 
Running Head: The Economic Deterioration of the Family

Households, eds. R. M. Blank and M. S. Barr, pp. 218-56. New York: Russell Sage Foundation.

Bowles, S., Gordon, D. M. and Weisskopf, T. E. (1989). "Business Ascendancy and Economic Impasse: A Structural Retrospective on Conservative Economics, 197987." Journal of Economic Perspectives 3(1): 107-34.

------.(1990). After the Wasteland: A Democratic Economics for the Year 2000. Armonk, NY: M.E. Sharpe, Inc.

Boyer, R. (2010). "The Rise of CEO Pay and the Contemporary Social Structure of Accumulation in the United States." In Contemporary Capitalism and its Crises: Social Structure of Accumulation Theory for the Twenty-First Century, eds. T. McDonough, M. Reich and D. M. Kotz, pp. 215-38. Cambridge: Cambridge University Press.

Bucks, B. K., Kennickell, A. B., Mach, T. L. and Moore, K. B. (2009). "Changes in U.S. Family Finances from 2004 to 2007: Evidence from the Survey of Consumer Finances." Federal Reserve Bulletin 95 (February): A1-A56.

Bureau of Economic Analysis. 2009. "National Income and Product Accounts Table: Table 1.12. National Income by Type of Income, Line 15." Washington, DC. http://www.bea.gov/national/nipaweb.

------.2010. "National Income and Product Accounts Table: Table 2.1. Personal Income and its Disposition." Washington, DC. http://www.bea.gov/national/nipaweb. Carlson, S. M., Gillespie, M. D. and Michalowski, R. J. (2010). "Social Structures of Accumulation and the Criminal Justice System." In Contemporary Capitalism and its Crises: Social Structure of Accumulation Theory for the Twenty-First Century, eds. T. 
Running Head: The Economic Deterioration of the Family

McDonough, M. Reich and D. M. Kotz, pp. 239-66. Cambridge: Cambridge University Press.

Carter, S. B., Gartner, S. S., Haines, M. R., Olmstead, A. L., Sutch, R., Wright, G. and , . 2006. "Historical Statistics of the United States Millennial Edition Online." Cambridge University Press New York. http://hsus.cambridge.org/HSUSWeb/HSUSEntryServlet.

Collins, J. L., and Mayer, V. (2010). Both Hands Tied: Welfare Reform and the Race to the Bottom in the Low-Wage Labor Market. Chicago: University of Chicago Press.

Collins, R. (1975). Conflict Sociology: Toward an Explanatory Science. New York: Academic Press.

Coontz, S. (1992). The Way We Never Were: American Families and the Nostalgia Trap New York: Basic Books.

Creed, G. W. (2000). "'Family Values" and Domestic Economies." Annual Review of Anthropology 29(1): 329-55.

Cromwell, J. B., Labys, W. C. and Terraza, M. (1994). Univariate Tests for Time Series Models. Thousand Oaks, CA: Sage Publications.

Danziger, S., and Haveman, R. H. (2001). Understanding Poverty. New York: Russell Sage Foundation.

Dickinson, J., and Russell, B., editors. 1986. Family, Economy and State: The Social Reproduction Process Under Capitalism. New York: St. Martin's Press.

Engels, F. ([1884] 2001). Origins of the Family, Private Property and the State. London: ElecBook. 
Running Head: The Economic Deterioration of the Family

Federal Deposit Insurance Corporation. 2010. "CB02: Changes in Number of Institutions FDIC-Insured Commercial Banks United States and Other Areas." Washington, DC. http://www2.fdic.gov/hsob/HSOBRpt.asp.

Federal Reserve Board of Governors. 2010a. "Statistical Release Z.1 (March 11, 2010):

Flow of Funds Accounts of the United States, Table B.100." Washington, DC.

------.2010b. "Total Consumer Credit Outstanding, Release G-19: Series TOTALNS."

Board of Governors of the Federal Reserve System, Washington, DC.

Goldberg, G. S., and Collins, S. D. (2001). Washington's New Poor Law: Welfare

"Reform" and the Roads Not Taken, 1935 to the Present. New York: Apex Press.

Goldberger, A. S. (1991). A Course in Econometrics. Cambridge, MA: Harvard University Press.

Goodman, P. S. (2009). Past due: The End of Easy Money and the Renewal of the American Economy. New York: Henry Holt and Co.

Gordon, D. M., Edwards, R. and Reich, M. (1982). Segmented Work, Divided Workers: The Historical Transformation of Labor in the United States. New York: Cambridge University Press.

Gough, I. (1979). The Political Economy of the Welfare State. London: MacMillan.

Griffin, L. J. (1992). "Temporality, Events, and Explanation in Historical Sociology: An Introduction." Sociological Methods Research 20(4): 403-27.

Harvey, D. (2005). A Brief History of Neoliberalism. New York: Oxford University Press.

Hassett, K. A., and Moore, A. (2006). "How do Tax Policies Affect Low-Income Workers?" In Working and Poor: How Economic and Policy Changes are Affecting 
Running Head: The Economic Deterioration of the Family

Low-Wage Workers, eds. R. M. Blank, S. H. Danziger and R. F. Schoeni, pp. 265-88. New York: Russell Sage Foundation.

Hays, S. (2003). Flat Broke with Children: Women in the Age of Welfare Reform. New York: Oxford University Press.

Howell, B. (2006). "Exploiting Race and Space: Concentrated Subprime Lending as Housing Discrimination." California Law Review 94(1): 101-47.

Internal Revenue Service. 2010. "SOI Tax Stats - Individual Income Tax Returns: Table 4." Washington, DC.

http://www.irs.gov/taxstats/indtaxstats/article/0,,id=133414,00.html.

Jessop, B. (2007). State Power: A Strategic-Relational Approach. Malden, MA: Polity.

Katz, M. B. (1996). In the Shadow of the Poor House: A Social History of Welfare in America. Rev. ed. New York: Basic Books.

Kotz, D. M. (1994). "Household Labor, Wage Labor, and the Transformation of the Family." Review of Radical Political Economics 26(2): 24-56.

------.(2009). "The Financial and Economic Crisis of 2008: A Systemic Crisis of Neoliberal Capitalism." Review of Radical Political Economics 41(3): 305-17.

Marx, K. (1998). The German Ideology: Including Theses on Feuerbach and the Introduction to the Critique of Political Economy. Amherst, NY: Prometheus Books. McDonough, T. (2008). "Social Structures of Accumulation Theory: The State of the Art." Review of Radical Political Economics 40(2): 153-73.

McLean, B., and Nocera, J. (2010). All the Devils are here: The Hidden History of the Financial Crisis. New York: Portfolio/Penguin.

Mills, C. W. (1959). The Sociological Imagination. New York: Oxford University Press. 
Running Head: The Economic Deterioration of the Family

Morgen, S., Acker, J., Weigt, J. and Gonzales, L. (2006). "Living Economic

Restructuring at the Bottom: Welfare Restructuring and Low-Wage Work." In The Promise of Welfare Reform: Political Rhetoric and the Reality of Poverty in the

Twenty-First Century, eds. K. M. Kilty and E. A. Segal, pp. 81-94. Binghamton, NY:

Hawthorn Press.

Neubeck, K. J. (2006). When Welfare Disappears: The Case for Economic Human Rights. New York: Routledge.

Newman, K. S. (2006). Chutes and Ladders: Navigating the Low-Wage Labor Market. New York: Russell Sage Foundation.

O'Connor, J. (1973). The Fiscal Crisis of the State. New York: St. Martin's Press.

O'Hara, P. A. (1995). "Household Labor, the Family, and Macroeconomic Instability in the United States: 1940s-1990s." Review of Social Economy 53(1): 89-120.

Parsons, T., and Bales, R. F. (1955). Family, Socialization and Interaction Process. Glencoe, Il: Free Press.

Pattillo-McCoy, M. (1999). Black Picket Fences: Privilege and Peril among the Black Middle Class. Chicago: University of Chicago Press.

Piven, F. F., Acker, J., Hallock, M. and Morgen, S., editors. 2002. Work, Welfare, and Politics: Confronting Poverty in the Wake of Welfare Reform. Eugene, OR: University of Oregon Press.

Piven, F. F., and Cloward, R. A. (1997). The Breaking of the American Social Compact. New York: New Press.

Pressman, S., and Scott, R. (2009a). "Consumer Debt and the Measurement of Poverty and Inequality in the United States." Review of Social Economy 67(2): 127-46. 
Running Head: The Economic Deterioration of the Family

------.(2009b). "Who are the Debt Poor?" Journal of Economic Issues 43(2): 423-32.

Reinhart, C. M., and Rogoff, K. S. (2009). This Time is Different: Eight Centuries of Financial Folly. Princeton, NJ: Princeton University Press.

Sidel, R. (2006). Unsung Heroines: Single Mothers and the American Dream. Berkeley, CA: University of California Press.

Social Security Administration. 2008. "Statistical Abstract of the United States: 2000." Washington, DC.

------.2010. "Statistical Abstract of the United States: 2009." Washington, DC.

Sorkin, A. R. (2009). Too Big to Fail: The Inside Story of how Wall Street and Washington Fought to Save the Financial System--and Themselves. New York: Viking.

Spiegel, J. W., and Gart, A. (1996). "What Lies Behind the Bank Merger and Acquisition Frenzy?" Business Economics 31(2): 47-52.

Swenson, D. (2004). A Neo-Functionalist Synthesis of Theories in Family Sociology. Lewiston, New York: The Edwin Mellen Press.

Tax Policy Center. 2011. "Earned Income Tax Credit: Number of Recipients and Amount of Credit, 1975-2009." Urban Institute and Brookings Institution Washington, DC. http://www.taxpolicycenter.org/taxfacts/displayafact.cfm?DocID=37\&Topic2id=40\& Topic3id=42.

Teplin, A. M. (2001). "The U.S. Flow of Funds Accounts and their Uses." Federal Reserve Bulletin 87 (July): 431-41. 
Running Head: The Economic Deterioration of the Family

Turner, L. J., Danziger, S. and Seefeldt, K. S. (2006). "Failing the Transition from Welfare to Work: Women Chronically Disconnected from Employment and Cash Welfare." Social Science Quarterly 87(2): 227-49.

U.S. Bureau of Labor Statistics. 2010. "(Unadj) Unemployment Rate Series LNU04000000." U.S. Department of Labor Washington, DC. http://data.bls.gov/PDQ/servlet/SurveyOutputServlet?data_tool=latest_numbers\&seri es_id=LNU04000000\&years_option=all_years\&periods_option=specific_periods\&pe $\underline{\text { riods=Annual+Data. }}$

U.S. Census Bureau. 2009. "Historical Income Table - Families: Table F-2, Share of Aggregate Income Received by each Fifth and Top 5 Percent of Families, all Races: 1947 to 2007." Washington, DC.

Warren, E., and Tyagi, A. W. (2003). The Two-Income Trap: Why Middle-Class Mothers and Fathers are Going Broke. New York: Basic Books.

White, J. M., and Klein, D. M. (2008). Family Theories. 3rd ed. Los Angeles: Sage. Wilson, W. J. (1996). When Work Disappears: The World of the New Urban Poor. New York: Vintage Books.

Wolfson, M. H. (1994). Financial Crises: Understanding the Postwar U.S. Experience. 2nd ed. Armonk, NY: M.E. Sharpe.

Wolfson, M. H., and Kotz, D. M. (2010). "A Reconceptualization of SSA Theory." In Contemporary Capitalism and its Crises: Social Structure of Accumulation Theory for the Twenty-First Century, eds. T. McDonough, M. Reich and D. M. Kotz, pp. 7290. Cambridge: Cambridge University Press. 
Running Head: The Economic Deterioration of the Family

Zaretsky, E. (1976). Capitalism, the Family, and Personal Life. New York: Harper Colophon. 